\title{
Synthesis of D-pantolactone via Combined a Novel Organocatalyst Catalyzed Asymmetric Aldol Reaction and Hydrogenation Catalyzed by $\mathrm{Cu}-/ \mathrm{SiO}_{2}$
}

\author{
Jin Man-man ${ }^{1}$, Wang Jin-jin ${ }^{1}$, Lv Zhi-guo ${ }^{1}$, Guo Zhen-mei ${ }^{2, *}$ \\ ${ }^{1}$ College of Chemical Engineering, Qingdao University of Science and Technology, Qingdao, China \\ ${ }^{2}$ College of Marine Science and Biological Engineering, Qingdao University of Science and Technology, Qingdao, China
}

\section{Email address:}

13864220985@163.com (Jin Man-man),1024515524@qq.com (Wang Jin-jin), guoguolv@sina.com (Lv Zhi-guo), huagongguozhenmei@163.com (Guo Zhen-mei)

${ }^{*}$ Corresponding author

To cite this article:

Jin Man-man, Wang Jin-jin, Lv Zhi-guo, Guo Zhen-mei. Synthesis of D-pantolactone via Combined a Novel Organocatalyst Catalyzed Asymmetric Aldol Reaction and Hydrogenation Catalyzed by Cu-/SiO 2. American Journal of Applied Chemistry. Vol. 5, No. 4, 2017 , pp. $62-68$. doi: 10.11648/j.ajac.20170504.12

Received: June 21, 2017; Accepted: August 1, 2017; Published: August 14, 2017

\begin{abstract}
The combination of an asymmetric organocatalytic aldol reaction with a subsequent hydrogenation for the synthesis of D-pantolactone is demonstrated. This process consists of an initial aldol reaction catalyzed by a novel chiral Lhistidine-modified-ionic-liquid- [EMIm] [His], which has been designed and synthesized as an efficient recoverable catalyst for the asymmetric aldol reaction with superior enantioselectivity in $\mathrm{CH}_{2} \mathrm{Cl}_{2}$, than L-histidine itself. [EMIm] [His] retains its activity and enantioselectivity over at least five reaction cycles, and its universal applicability has been demonstrated. Moreover optimum process of $\mathrm{Cu}-\mathrm{SiO}_{2}$-catalysed hydrogenation of condensation product- (D) -3- formyl -2- hydroxy -3- ethyl butyrate to obtain D-pantolactone has been established allowing the synthesis of D-pantolactone in $>99 \%$ purity, $93 \%$ yield and $93 \%$ enantiomeric excesse (ee). The results show that $\mathrm{CuO}-\mathrm{CeO}_{2} / \mathrm{SiO}_{2}$ exhibits better catalytic activity than $\mathrm{CuO} / \mathrm{SiO}_{2}$ for better dispersion and larger surface area, and the best reaction conditions are as follows: $120^{\circ} \mathrm{C}, n\left(\mathrm{H}_{2}\right): n$ (isobutylaldehyde) $=80: 1, \mathrm{P}\left(\mathrm{H}_{2}\right)=8.0 \mathrm{MPa}$, liquid airspeed: $0.6 \mathrm{~h}^{-1}$.
\end{abstract}

Keywords: Asymmetric Aldol Reaction, Organocatalyst, L-Histidine-Modified-Ionic-Liquid, D-Pantolactone, $\mathrm{Cu}-\mathrm{SiO}_{2}$, Hydrogenation

\section{Introduction}

D-pantolactone continues to be of interest to organic chemists due to its wide use as a chiral auxiliary [1-3] and an important intermediate in the synthesis of calcium Dpantothenate $\left(\mathrm{C}_{18} \mathrm{H}_{32} \mathrm{CaN}_{2} \mathrm{O}_{10}\right)$ [4] which has the function of making antibodies [5] and is needed for the biosynthesis of CoA [6]. The mainly existing methods of the synthesis of D-pantolactone are based on the resolution of racemate ${ }^{6}$ or asymmetric hydrogenation of the precursor of D-pantolactone [7], the drawbacks of both are the long and complicated technologies, which have led to the need for calcium Dpantothenate to be imported so far. The precursor of D-pantolactone is mainly synthesized by aldol reaction as a key step that has promoted a rapid development of numerous highly enantioselective chiral catalysts [8-10]. In nature, small organic molecules, in particular amino acids [11-13] and their derivatives [14-17], are rich chiral sources, which are used as the catalysts, but with recycling problems, such as extensive work-up procedures with the corresponding waste generation or more time to recover the catalyst between two cycles [18-20]. However ionic liquids (ILs) have been widely used as environmentally benign solvents to replace common organic media [21] with advantages of reusable, strong design ability, low pollution, low toxicity, and excellent miscibility with organic compounds [22-24]. Because of the above-mentioned highly tunable characteristics (broad cation/anion combinations) and the enhancement of reaction efficiency by using ILs as solvents [25-26], ILs have gained wide recognition in specific engineering, especially as catalysts to 
catalyze aldol reactions [27-28]. So far poline-related-catalyzed asymmetric aldol reactions have been investigated extensively [29-31], but there are few reports on grafting L-histidine onto IL. Herein, L-histidine was selected and grafted onto IL to get a novel type of recyclable catalyst which can be recovered quickly and simply between two cycles by solubility difference between substrate, solvent and the product mixture as illustrated in Figure 1.

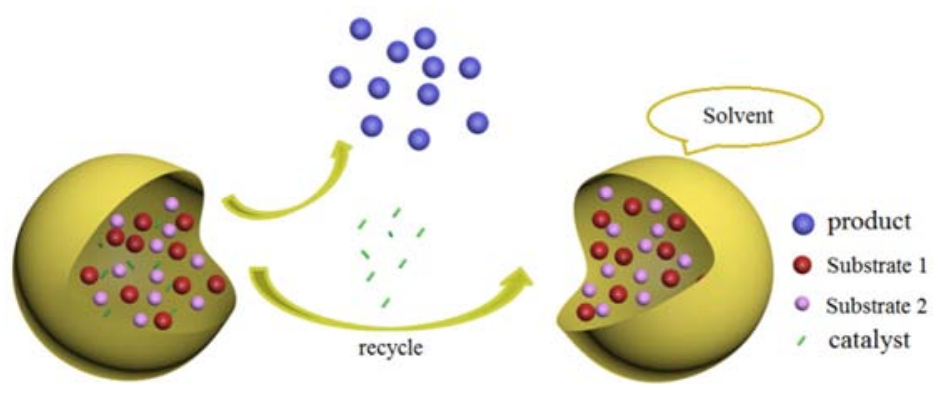

Figure 1. General concept of ionic-liquid-supported catalysis.

$\mathrm{Cu}$-based catalyst had been widely known to activate hydrogen molecules and employed as hydrogenation catalysts, because of their high selectivity and stability [32-34]. So we synthesized $\mathrm{CuO} / \mathrm{SiO}_{2}$ and $\mathrm{CuO}-\mathrm{CeO}_{2} / \mathrm{SiO}_{2}$ to catalyze the asymmetric hydrogenation reaction. Under the optimized condition of asymmetric hydrogenation for precursor-(D) -3formyl -2- hydroxy -3- ethyl butyrate to obtain D-pantolactone with purity more than $99 \%, 93 \%$ yield and $93 \%$ ee, which lends this route a bright prospect in future industrial production.

\section{Experimental}

\subsection{General Remarks}

All reagents were obtained from commercial sources and used without further purification except for isobutanal, which was distilled before use and took $40 \sim 42^{\circ} \mathrm{C}$ distillate, and deionized water was always needed. ${ }^{1} \mathrm{H}$ NMR spectra was recorded on a $500 \mathrm{MHz}$ instrument (kerAvance 500). Chemical shift was reported in parts per million (ppm, $\delta$ ) downfield from residual $\mathrm{CHCl}_{3}$ signal $(\delta(1 \mathrm{H}), 7.26 \mathrm{ppm})$. Proton coupling patterns were described as singlet (s), multiplet (m). The aldol product- (D) -3- formy 1-2- hydroxy -3- ethyl butyrate was also characterized by gas chromatograph-mass spectrometer (GC-MS) with a DB-35 $\mathrm{ms}$ column. The temperature was regulated at $60^{\circ} \mathrm{C}$ for $2 \mathrm{~min}$, heated to $260^{\circ} \mathrm{C}$ at $10^{\circ} \mathrm{C} / \mathrm{min}$, and maintained at $260^{\circ} \mathrm{C}$ for 5 min. D-pantolactone was characterized by GC-MS with the above-mentioned settings, but the temperature was different which was regulated at $70^{\circ} \mathrm{C}$ for $2 \mathrm{~min}$, heated to $250^{\circ} \mathrm{C}$ at $10^{\circ} \mathrm{C} / \mathrm{min}$, and maintained for $5 \mathrm{~min}$. Ee values of D-pantolactone and (D) -3- formyl -2- hydroxy -3- ethyl butyrate were determined using WZZ-2 $\mathrm{S}$ digital automatic polarimeter with water and $\mathrm{CHCl}_{3}$ were used as solvents respectively. Quantitative gas chromatography (GC) for conversion determination of (D) -3- formyl -2- hydroxy -3ethyl butyrate was carried out on PEG column $(30 \mathrm{~m} \times 0.22$ $\mathrm{mm} \times 0.25 \mu \mathrm{m}$ ) at $240^{\circ} \mathrm{C}$ (isotherm, $4 \mathrm{~min}$ ) with $\mathrm{N}_{2}$ as a carrier gas. The conversion of D-pantolactone was also determined with the above-mentioned settings, just a different temperature $\left(220^{\circ} \mathrm{C}\right)$.
The X-ray diffraction patterns were recorded on D-MAX 2500-PC (Rigaku Corp.) operated at $50 \mathrm{kV}$ and $200 \mathrm{~mA}$ equipped with nickel-filtered $\mathrm{Cu} \mathrm{K} \alpha$ radiation $(\lambda=1.5418 \AA$ ). The SEM images of $\mathrm{Cu}-/ \mathrm{SiO}_{2}$ were recorded on a scanning electron microscope (JEOL-6700 F, Japan Electron Co., Ltd.)

\subsection{Preparation of Ionic-Liquid-Supported-Catalyst-[EMIm] [His]}

As synthesis procedure [35], to $40 \mathrm{~mL}$ of bromic ether and $40 \mathrm{~mL}$ of ethyl acetate was added a mixed solution containing $20 \mathrm{~mL}$ of $\mathrm{N}$ - methyl imidazole and $20 \mathrm{~mL}$ of acetate. The reaction mixture was heated at room temperature for $6 \mathrm{~h}$ under magnetic stirring and refluxing. The white precipitate was then added a mixed solution containing $20 \mathrm{~mL}$ of methyl cyanide and $70 \mathrm{~mL}$ of ethyl acetate for recrystallization. The intermediate- [EMIm] $\mathrm{Br}$ was obtained with $92 \%$ yield. $1 \mathrm{H}$ NMR (CDCl3, $500 \mathrm{MHz}): \delta 10.21(\mathrm{~s}, 1 \mathrm{H}, \mathrm{NCHN}), 7.66(\mathrm{~s}, 1 \mathrm{H}$, $\mathrm{NCH}), 7.37$ (s, 1H, NCH), 4.45 (t, 2H, NCH2), 4.13 (s, 3H, $\mathrm{NCH} 3), 1.62$ (t, 3H, CH3).

[EMIm] $\mathrm{OH}$ was prepared according to the following method: to $5.73 \mathrm{~g}(0.03 \mathrm{~mol})$ of [EMIm] $\mathrm{Br}$ was added appropriate amount of isopropyl alcohol. The reaction mixture was added equivalent molar of $\mathrm{KOH}$ and heated at $323 \mathrm{~K}$ under magnetic stirring for $10 \mathrm{~h}$. After filtered and evaporated, the mixture was dissolved in $\mathrm{CH}_{2} \mathrm{Cl}_{2}$, then added appropriate amount of active carbon under magnetic stirring for $10 \mathrm{~h}$. Subsequently, the mixture was filtered, evaporated solvent, extracted with ether for three times, and then dried in vacuum for $10 \mathrm{~h}$.

To an aqueous solution of $4.65 \mathrm{~g}(0.03 \mathrm{~mol})$ of L-histidine was added appropriate amount of an aqueous solution of [EMIm] OH. The reaction mixture was heated at room temperature under magnetic stirring for $24 \mathrm{~h}$. After evaporating solvent, the buff precipitate was added a mixed solution containing $60 \mathrm{~mL}$ of acetonitrile and $10 \mathrm{~mL}$ methanol at room temperature under vigorous magnetic stirring for $2 \mathrm{~h}$. The solid was filtered and evaporated to remove the unreacted L-histidine and solvent, dried in vacuum at $353 \mathrm{~K}$ for $24 \mathrm{~h}$, then [EMIm] [His] was obtained. 1H NMR (CDCl3, 500MHz): $\delta 1.52(\mathrm{t}, 3 \mathrm{H}, \mathrm{CH} 3), 1.93-2.09(\mathrm{~m}, 2 \mathrm{H}), 3.07(\mathrm{~m}$, 2H), 3.90 (s, 1H), 4.23 (s, 3H, NCH3), 4.49 (t, 2H, NCH2), $6.86(\mathrm{~m}, 1 \mathrm{H}), 7.72(\mathrm{~s}, 1 \mathrm{H}, \mathrm{NCH}), 7.77(\mathrm{~s}, 1 \mathrm{H}), 7.89(\mathrm{~s}, 1 \mathrm{H})$, 


\section{$10.11(\mathrm{~s}, 1 \mathrm{H}, \mathrm{NCHN})$.}

\subsection{General Procedure for [EMIm] [His]-Catalyzed Aldol Reaction Using Ethyl Glyoxylate and Isobutanal}

To a solution of $2.04 \mathrm{~g}(0.01 \mathrm{~mol})$ of ethyl glyoxylate and $10-40 \mathrm{~mol} \%$ (each with reference to ethyl glyoxylate) of [EMIm] [His] in $2 \mathrm{~mL}$ solvent was added $0.86 \mathrm{~g}(0.012 \mathrm{~mol})$ of isobutanal all at once and reacted for 5-72 $\mathrm{h}$ under magnetic stirring. The reaction mixture was washed with deionized water $(10 \mathrm{~mL} \times 3)$, extracted with ethyl acetate $(10 \mathrm{~mL} \times 3)$, dried over anhydrous magnesium sulfate. Colorless oily viscous liquid - (D) -3- formy 1-2- hydroxy -3- ethyl butyrate was obtained. ${ }^{1} \mathrm{H}$ NMR $\left(\mathrm{CDCl}_{3}, 500 \mathrm{MHz}\right): \delta 1.26(\mathrm{~s}, 3 \mathrm{H}$, $\left.-\mathrm{CH}_{3}\right), 1.27\left(\mathrm{~s}, 3 \mathrm{H},-\mathrm{CH}_{3}\right), 3.58(\mathrm{~s}, 1 \mathrm{H}, \mathrm{OH}), 4.32(\mathrm{~m}, 2 \mathrm{H}$, $\left.-\mathrm{CH}_{2}-\right), 4.37(\mathrm{~s}, 1 \mathrm{H},-\mathrm{CH}-), 9.62(\mathrm{~s}, 1 \mathrm{H},-\mathrm{CHO}) . \mathrm{GC}$ (quantitative, GC 6890): $\operatorname{tr}=13.490 \mathrm{~min}$.

\subsection{Preparation of $\mathrm{Cu}-\mathrm{SiO}_{2}$}

The preparation of $\mathrm{CuO} / \mathrm{SiO}_{2}$ was prepared via the method of co-precipitation. Aqueous solution of $\mathrm{Cu}\left(\mathrm{NO}_{3}\right)_{2} \cdot 3 \mathrm{H}_{2} \mathrm{O}$ and aqueous solution of $\mathrm{NaOH}$ were added slowly into a three-necked flash under vigorous stirring at $45^{\circ} \mathrm{C}$, then silica sol was added to the precipitation system. Finally, the resulting suspension was aged at $80^{\circ} \mathrm{C}$ for $6 \mathrm{~h}$ under stirring, and then filtered and washed with a large amount of deionized water. The precipitates were dried overnight and calcined for $6 \mathrm{~h}$ at $500^{\circ} \mathrm{C}$ in air to obtain the final catalyst. $\mathrm{CuO}-\mathrm{CeO}_{2} / \mathrm{SiO}_{2}$ was prepared the same way as $\mathrm{CuO} / \mathrm{SiO}_{2}$, except for adding an appropriate amount of $\mathrm{H}_{12} \mathrm{CeN}_{3} \mathrm{O}_{15}$ solution.

\subsection{General Procedure for the Synthesis of D-pantolactone}

D-pantolactone was obtained by (D) -3- formyl -2- hydroxy -3- ethyl butyrate via a fixed bed continuous hydrotreating catalyzed by $\mathrm{CuO} / \mathrm{SiO}_{2}$ and $\mathrm{Cuo}-\mathrm{CeO}_{2} / \mathrm{SiO}_{2}$ under the conditions of $80-160^{\circ} \mathrm{C}, n\left(\mathrm{H}_{2}\right)(2-9 \mathrm{Mpa}): n$ (isobutanal) $=$ 40-100:1, liquid airspeed 0.6-1.4 $\mathrm{h}^{-1}$ and vacuum distillation $(0.096 \mathrm{MPa})$ [36]. GC-MS: $\mathrm{t}_{\mathrm{r}}=7.379 \mathrm{~min}, \quad m / z=71 \quad\left(-\mathrm{C}_{4} \mathrm{H}_{7} \mathrm{O}\right)$ $\left(m / z=57 \quad\left(-\mathrm{C}_{3} \mathrm{H}_{5} \mathrm{O}\right), \quad m / z=14 \quad\left(-\mathrm{CH}_{2}\right)\right), \quad m / z=59 \quad\left(-\mathrm{C}_{2} \mathrm{H}_{3} \mathrm{O}_{2}\right)$ $\left(m / z=43\left(-\mathrm{C}_{2} \mathrm{H}_{3} \mathrm{O}\right), m / z=16\left(-\mathrm{CH}_{2}\right)\right)$.

\section{Results and Discussion}

We systematically tested some L-amino acids in the aldol addition of isobutanal to ethyl glyoxylate, and the results are depicted in Table 1. The relatively high yield and ee (entry 1, Table 1) demonstrated the suitability of L-histidine as a catalyst for this reaction. We thus selected L-histidine to graft onto IL to get a novel type of recyclable catalyst according to Figure 2.

Table 1. L-amino acids catalyzed aldol reaction.

\begin{tabular}{lllllll}
\hline Entry & L-amino acid & Solvent $^{\mathbf{a}}$ & Reaction time $^{\mathbf{b}} \mathbf{( h )}$ & Catalyst content $^{\mathbf{c}} \mathbf{( m o l \% )}$ & Yield $^{\mathbf{d}} \mathbf{( \% )}$ & Ee (\%) $^{\mathbf{\%}}$ \\
\hline 1 & histidine & glycol & 24 & 30 & 77 & 73 \\
2 & leucine & DMSO & 10 & 30 & 57.8 & 57 \\
3 & isoleucine & DMSO & 10 & 30 & 74.2 & 71 \\
4 & prolinamide & $\mathrm{CH}_{2} \mathrm{Cl}_{2}$ & 36 & 35 & 68 & 83 \\
5 & alanine & DMSO & 10 & 50 & 67 & 63 \\
6 & valine & DMSO & 10 & 50 & 71 & 70 \\
7 & lysine & DMSO & 12 & 50 & 88 & 12 \\
8 & asparagine & DMSO & 10 & 50 & 72 & 75 \\
9 & arginine & DMSO & 14 & 50 & 72 & 14 \\
10 & phenylalanine & DMSO & 10 & 50 & 73 & 69 \\
\hline
\end{tabular}

To a solution of $0.01 \mathrm{~mol}$ of ethyl glyoxylate and 10-60 mol\% (each with reference to ethyl glyoxylate) of L-amino acid in $2 \mathrm{ml}$ solvent was added $0.012 \mathrm{~mol}$ of isobutanal all at once and reacted for 5-72 h under magnetic stirring. ${ }^{\mathrm{a}}$ Optimal solvent, ${ }^{\mathrm{b}}$ optimal reaction time, ${ }^{\mathrm{c}}$ optimal catalyst content, ${ }^{\mathrm{d}}$ isolated yield.<smiles>Cn1ccnc1</smiles>

$\mathrm{N}$-methylimidazole

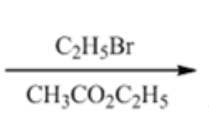

$\mathrm{CH}_{3} \mathrm{CO}_{2} \mathrm{C}_{2} \mathrm{H}_{5}$

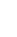

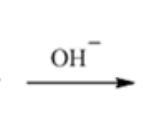<smiles></smiles>

[EMIm] $] \mathrm{OH}$<smiles>CC(C)[n+]1ccn(CC(N)C(=O)O)c1</smiles>

[EMIm][His]

Figure 2. Schematic illustration of synthesis of [EMIm] [His]. 


\subsection{The Influence of Solvent, Reaction Time, and Catalyst Content on the Aldol Reaction Rate Catalyzed by [EMIm] [His]}

To clarify role of solvent, reaction time, and catalyst content in [EMIm] [His]-catalysted aldol reaction, we varied the above-mentioned factors. As the results shown in Figure 3-5, maximum yield and ee were reached when the reaction was performed using $\mathrm{CH}_{2} \mathrm{Cl}_{2}$ as solvent. A lower yield of aldol product was isolated when more than $30 \mathrm{~mol} \%$ of [EMIm] [His] was used in the reaction. Meanwhile, it was found that the reaction was accomplished as the reaction was carried out for $30 \mathrm{~h}$.

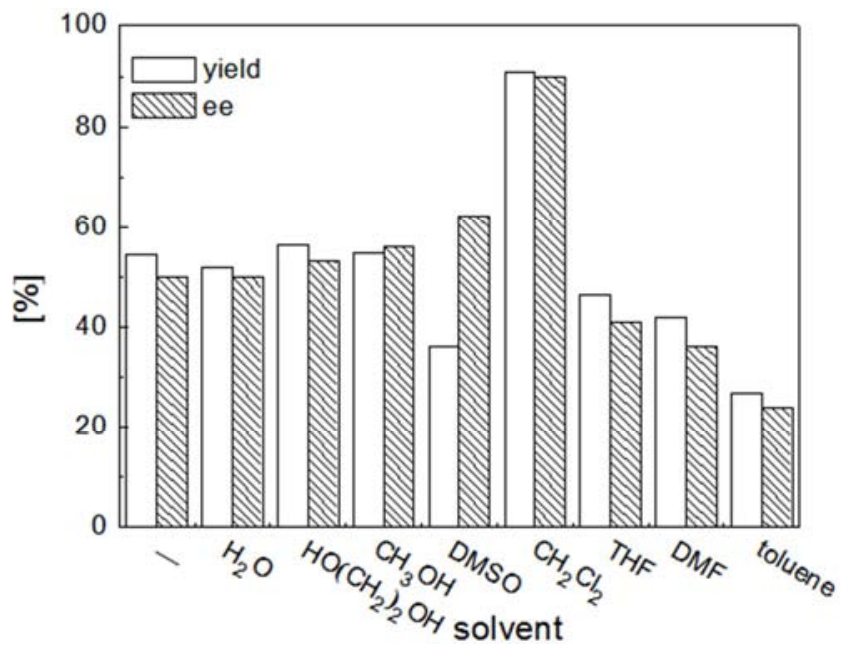

Figure 3. Influence of solvent on the reaction rate catalyzed by [EMIm] [His] Reaction conditions: catalyst content, $30 \mathrm{~mol} \%$; reaction time, $30 \mathrm{~h}$.

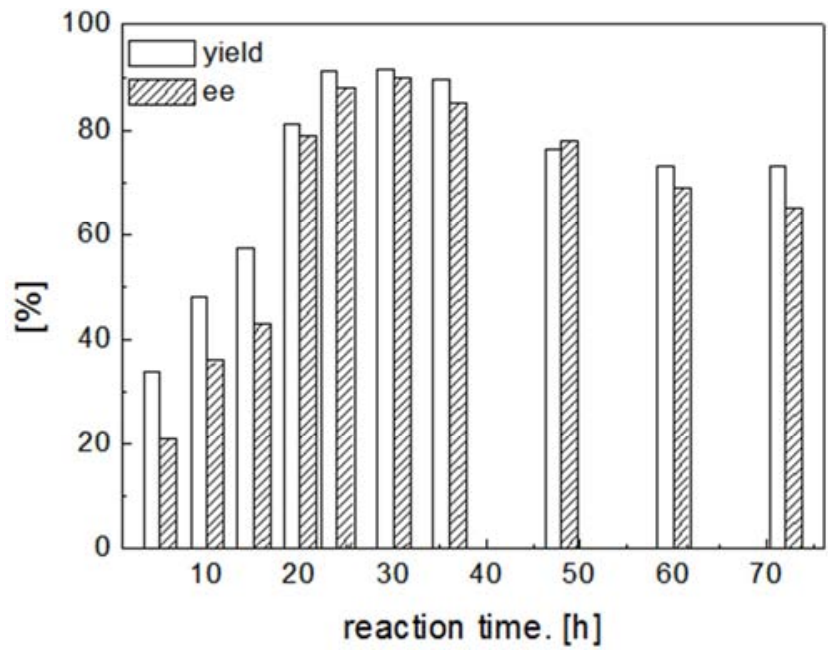

Figure 4. Influence of reaction time on the reaction rate catalyzed by [EMIm] [His]. Reaction conditions: solvent, $\mathrm{CH}_{2} \mathrm{Cl}_{2}$; catalyst content, $30 \mathrm{~mol} \%$.

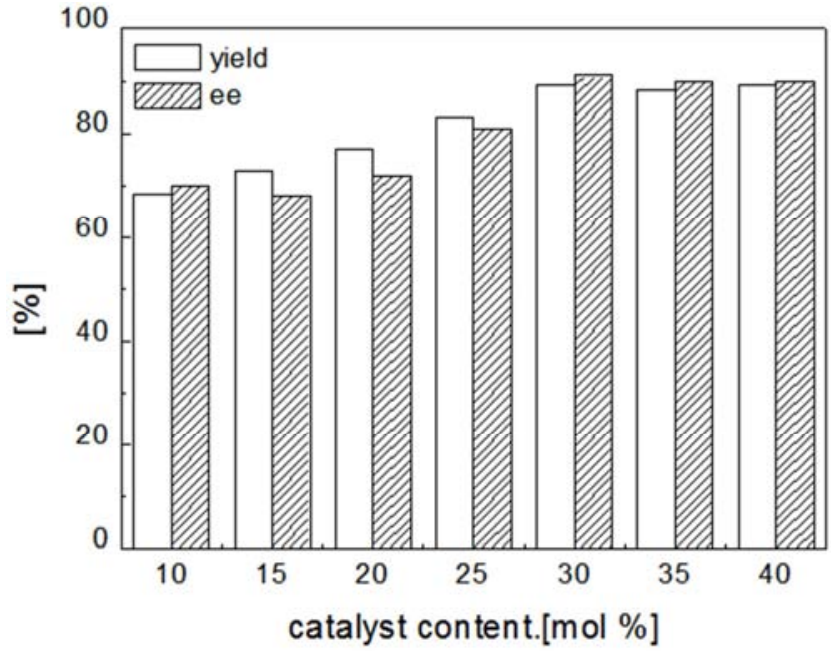

Figure 5. Influence of catalyst content on the reaction rate catalyzed by [EMIm] [His]. Reaction conditions: solvent, $\mathrm{CH}_{2} \mathrm{Cl}_{2}$; reaction time, $30 \mathrm{~h}$.

\subsection{Studies on the Universality of [EMIm ] [His]}

To test the general scope of the prepared [EMIm] [His] as catalyst, a series of enolizable aldehydes were subjected to the same reaction conditions except for the solvent (see Figure 6, Table 2 in the supporting information).

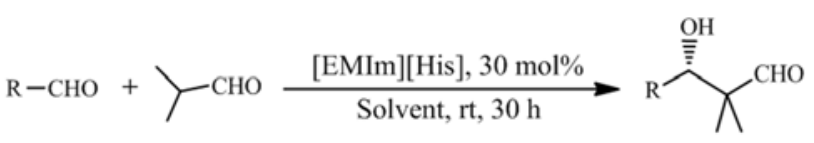

Figure 6. [EMIm] [His]-catalyzed aldol reaction between enolizable aldehydes.

Table 2. [EMIm] [His] and L-histidine catalyzed aldol reactions.

\begin{tabular}{|c|c|c|c|c|}
\hline Entry & $\mathbf{R}$ & Optimal solvent & Yield (\%) & Ee (\%) \\
\hline 1 & $\mathrm{EtO}_{2} \mathrm{C}$ & $\mathrm{CH}_{2} \mathrm{Cl}_{2}$ & $91\left(77^{\mathrm{a}}\right)$ & $95\left(73^{b}\right)$ \\
\hline 2 & $\mathrm{ClCH}_{2}$ & DMSO & $68\left(44^{\mathrm{a}}\right)$ & $89\left(72^{b}\right)$ \\
\hline 3 & $(\mathrm{MeO})_{2} \mathrm{CH}$ & DMSO & $89\left(91^{a}\right)$ & $99\left(99^{b}\right)$ \\
\hline 4 & $(\mathrm{Me})_{2} \mathrm{CHCH}_{2}$ & DMSO & $41\left(40^{\mathrm{a}}\right)$ & $99\left(97^{b}\right)$ \\
\hline 5 & $2-\mathrm{NO}_{2} \mathrm{C}_{6} \mathrm{H}_{4}$ & DMSO & $71\left(54^{a}\right)$ & $59\left(46^{\mathrm{b}}\right)$ \\
\hline 6 & 4- $\mathrm{BrC}_{6} \mathrm{H}_{4}$ & DMSO & $65\left(60^{a}\right)$ & $73\left(71^{b}\right)$ \\
\hline 7 & $\mathrm{Ph}$ & acetone & $49\left(49^{\mathrm{a}}\right)$ & $53\left(48^{b}\right)$ \\
\hline 8 & 4- $\mathrm{CNC}_{6} \mathrm{H}_{4}$ & acetone & $61\left(45^{\mathrm{a}}\right)$ & $60\left(52^{b}\right)$ \\
\hline 9 & 2- $\mathrm{ClC}_{6} \mathrm{H}_{4}$ & acetone & $90\left(88^{\mathrm{a}}\right)$ & $59\left(60^{b}\right)$ \\
\hline 10 & $4-\mathrm{NO}_{2}-\mathrm{C}_{6} \mathrm{H}_{4}$ & acetone & $80\left(53^{a}\right)$ & $65\left(70^{b}\right)$ \\
\hline
\end{tabular}

${ }^{a}$ Yield of aldol products catalyzed by L-histidine, ${ }^{b}$ ee of aldol products catalyzed by L-histidine.

We can see from Table 2 that the result was rather poor compared to that from the unsupported L-histidine under almost identical condition except for solvent. The aldol reactions catalyzed by two catalysts afforded nearly similar yields and ee values (entry3, 4, 6, 7, 9). [EMIm] [His]-catalyzed aldol reaction in $\mathrm{CH}_{2} \mathrm{Cl}_{2}$ using ethyl glyoxylate as enolizable aldehyde afforded highest yield and ee of aldol product (entry 1). In contrast to L-histidine as catalyst, the difference in yield and ee were up to $14 \%$ and $22 \%$ respectively. Those rendered 
[EMIm] [His]-catalyzed aldol reactions performed superior results than L-histidine itself.

\subsection{Studies on the Recycle of [EMIm] [His]}

We have also evaluated the recyclability of [EMIm] [His] as catalyst. The reaction between ethyl glyoxylate and isobutanal (entry 1, Table 2) shown the highest yield and ee, so they were served as a model reaction for the evaluation of [EMIm] [His]. When the first run of the reaction was completed, the reaction mixture was concentrated and rinsed with water for three times, extracting with ethyl acetate, drying, and recovering [EMIm] [His]. Fresh starting materials were charged into the reaction system, and the reaction still proceeded well. [EMIm] [His] was recycled five repetitive cycles with only minor decreases in product yields, but always maintenances ee value (see Figure 7 in the supporting information).

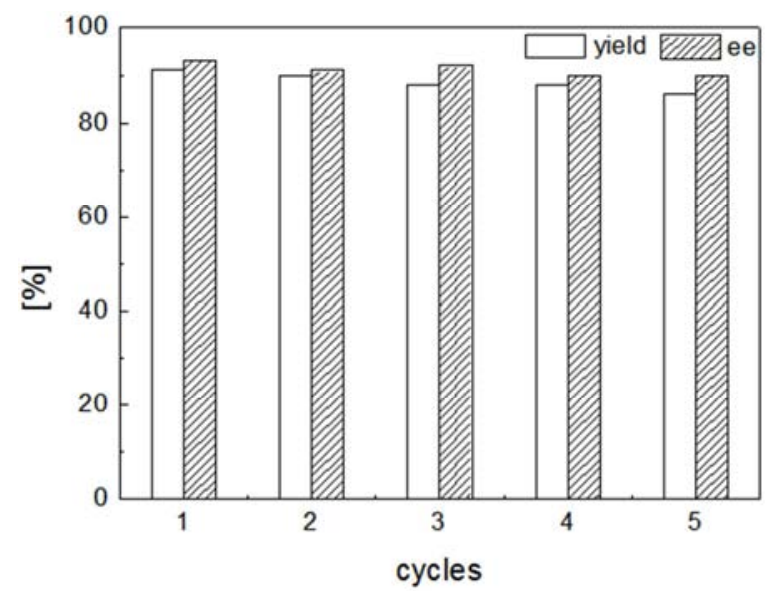

Figure 7. Reuse of [EMIm] [His]. Reaction conditions: solvent, $\mathrm{CH}_{2} \mathrm{Cl}_{2}$, reaction time, $30 \mathrm{~h}$; catalyst content, $30 \mathrm{~mol} \%$.

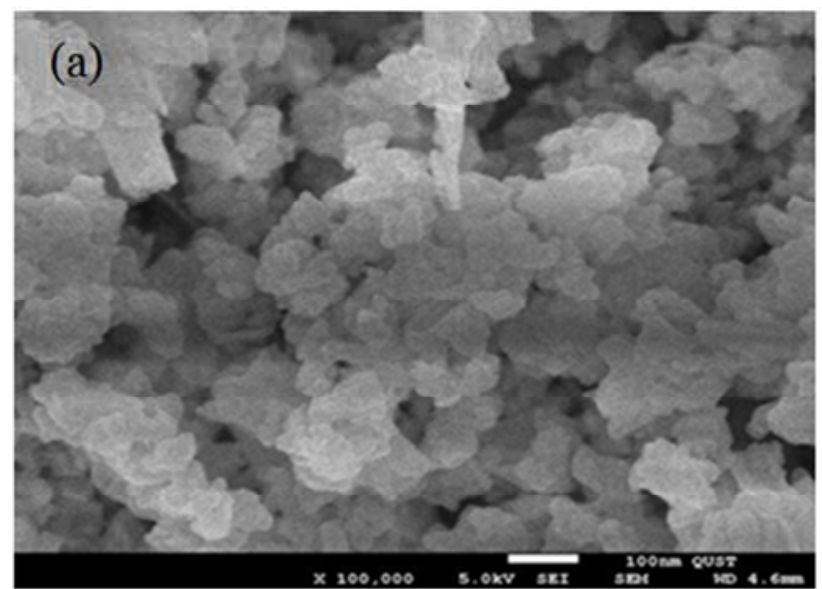

\section{4. $\mathrm{Cu}-/ \mathrm{SiO}_{2}$ Characterization}

The powder x-ray diffraction patterns of $\mathrm{Cu}-/ \mathrm{SiO}_{2}$ samples were shown in Fig. 8. From the XRD patterns, it can be observed that $\mathrm{Cu}-/ \mathrm{SiO}_{2}$ samples had retained $\mathrm{CuO}$ structure, by exhibiting three diffraction peaks at $2 \theta$ values around $35.7^{\circ}, 38.8^{\circ}$ and $48.6^{\circ} . \mathrm{CuO}-\mathrm{CeO}_{2} / \mathrm{SiO}_{2}$ shown relatively weak characteristic peaks of $\mathrm{CuO}$ in comparison with $\mathrm{CuO} / \mathrm{SiO}_{2}$, indicating the former had a smaller average particle size and better dispersion than the latter.

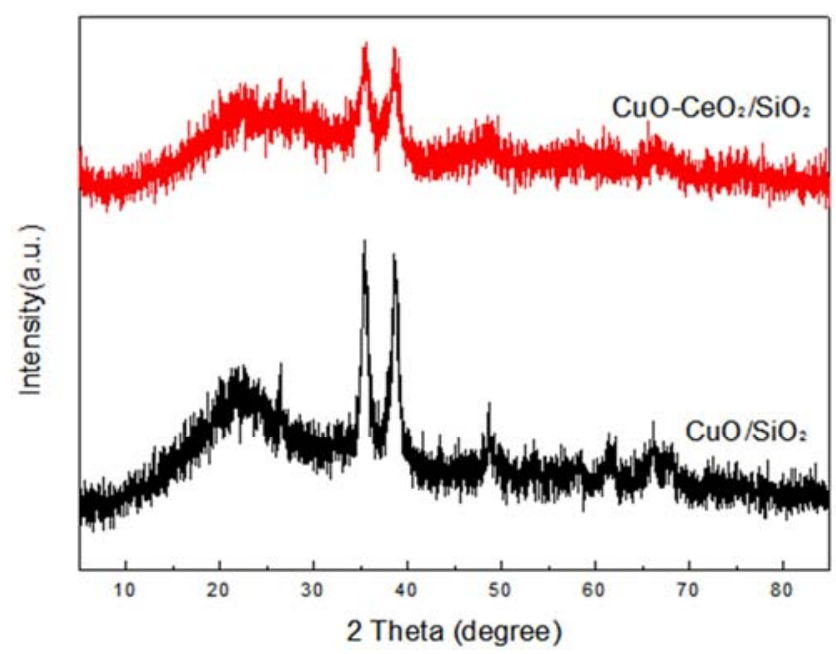

Figure 8. XRD patterns of $\mathrm{CuO} / \mathrm{SiO}_{2}$ and $\mathrm{CuO}-\mathrm{CeO}{ }_{2} / \mathrm{SiO}_{2}$.

SEM image of the $\mathrm{Cu}-/ \mathrm{SiO}_{2}$ samples were depicted in Fig. 9. The morphology of the $\mathrm{Cu}-/ \mathrm{SiO}_{2}$ samples were well dispersed with excellent resolution.

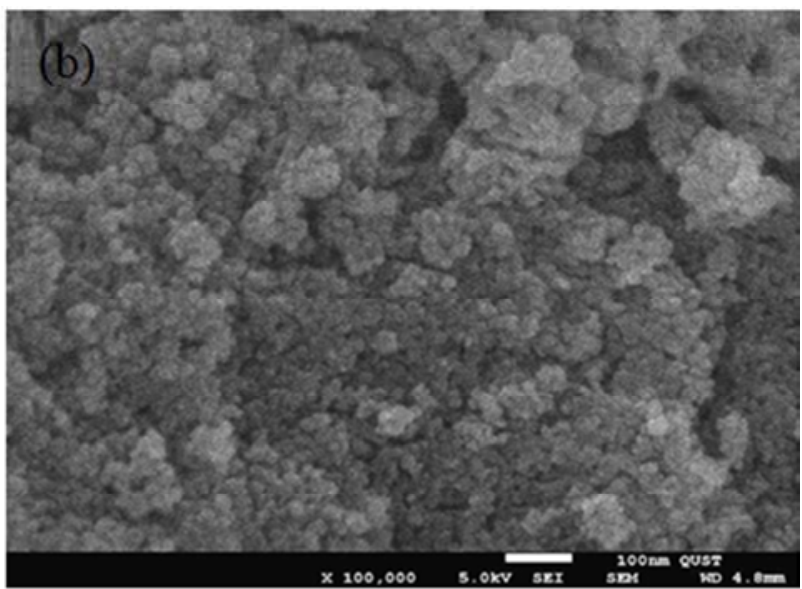

Figure 9. $\mathrm{SEM}$ images of $\mathrm{CuO} / \mathrm{SiO}_{2}$ (a) and $\mathrm{CuO}-\mathrm{CeO}_{2} / \mathrm{SiO}_{2}(\mathrm{~b})$.

\subsection{The Influence of Temperature, $\mathrm{H}_{2}$ Pressure, Liquid Airspeed, and Molar Ratio of $\mathrm{H}_{2}$ to Isobutanal on the Hydrogenation Catalyzed by $\mathrm{Cu}-/ \mathrm{SiO}_{2}$}

The Influence of temperature, $\mathrm{H}_{2}$ pressure, liquid airspeed, and molar ratio of $\mathrm{H}_{2}$ to isobutanal on the hydrogenation catalyzed by $\mathrm{Cu}-/ \mathrm{SiO}_{2}$ were shown in Figure 10-13, maximum yield of $\mathrm{D}$ - pantolactone was reached when the reaction was performed in $120^{\circ} \mathrm{C}$, molar ratio of $\mathrm{H}_{2}$ to isobutanal was $80: 1$, liquid airspeed was around $0.6 \mathrm{~h}^{-1}$, and $\mathrm{H}_{2}$ pressure was $8 \mathrm{MPa}$. Meanwhile, it was found that the catalytic activity of $\mathrm{CuO}-\mathrm{CeO}_{2} / \mathrm{SiO}_{2}$ was generally higher than that of $\mathrm{CuO} / \mathrm{SiO}_{2}$. 


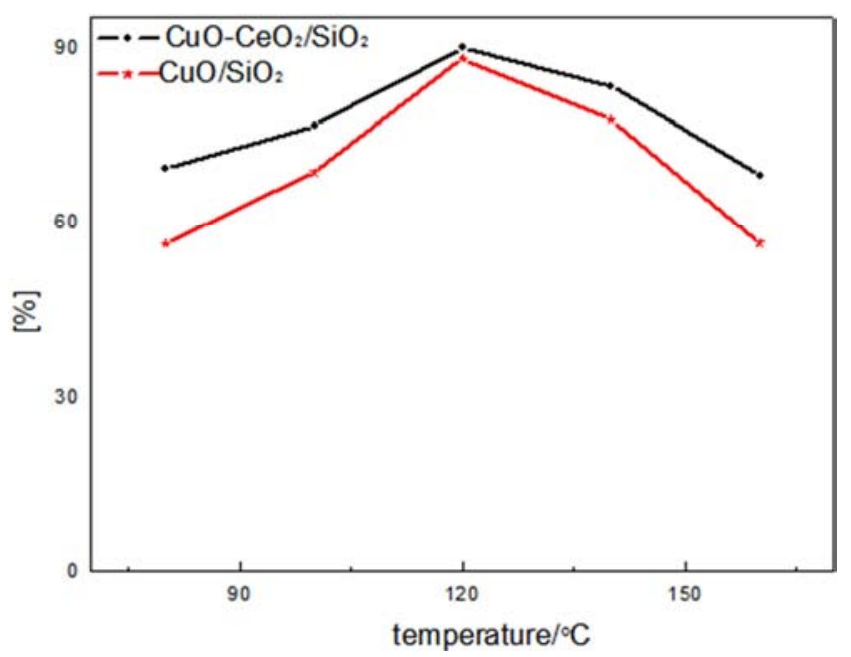

Figure 10. Influence of reaction temperature on the yield of D-pantolactone. Reaction conditions: $n\left(\mathrm{H}_{2}\right): n$ (isobutanal), 80:1; $\mathrm{H}_{2}$ pressure, $8 \mathrm{MPa}$; and liquid airspeed, $0.6 h^{-1}$.

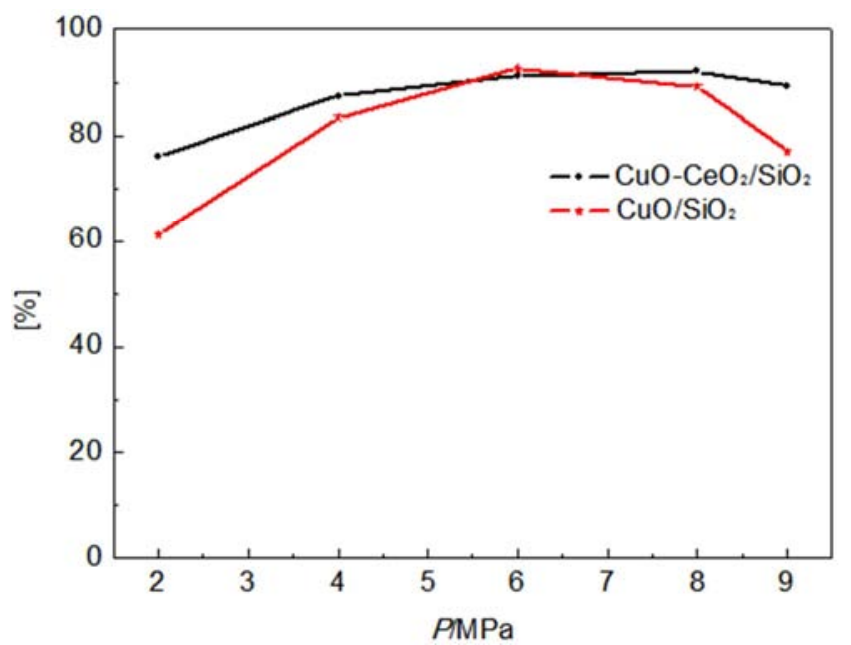

Figure 11. Influence of $\mathrm{H}_{2}$ pressure on the yield of D-pantolactone. Reaction conditions: $n\left(H_{2}\right): n$ (isobutanal), 80:1; liquid airspeed, $0.6 h^{-1}$; and temperature, $120^{\circ} \mathrm{C}$.

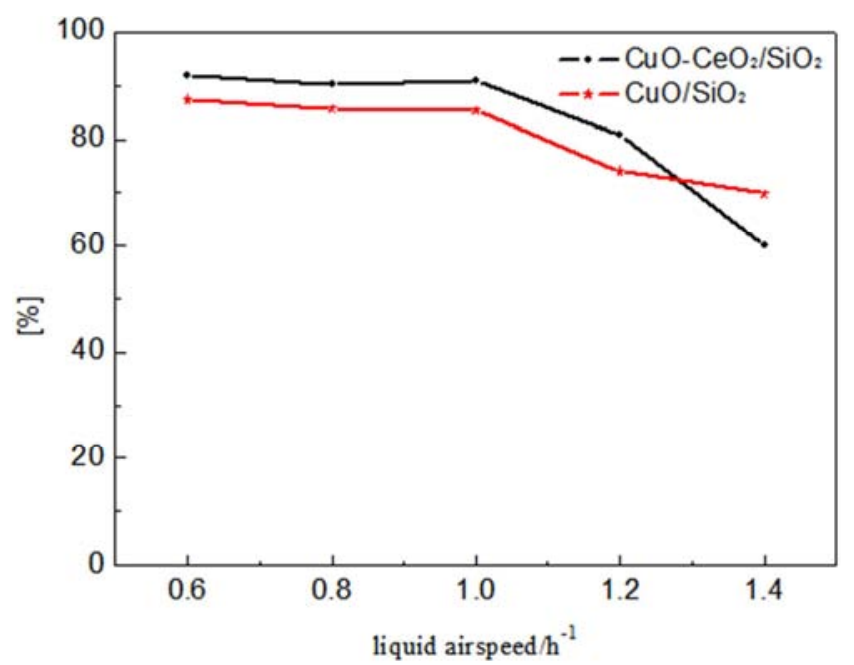

Figure 12. Influence of liquid airspeed on the yield of D-pantolactone. Reaction conditions: temperature, $120^{\circ} \mathrm{C} ; n\left(\mathrm{H}_{2}\right): n$ (isobutanal), 80:1; and $\mathrm{H}_{2}$ pressure, $8 \mathrm{MPa}$.

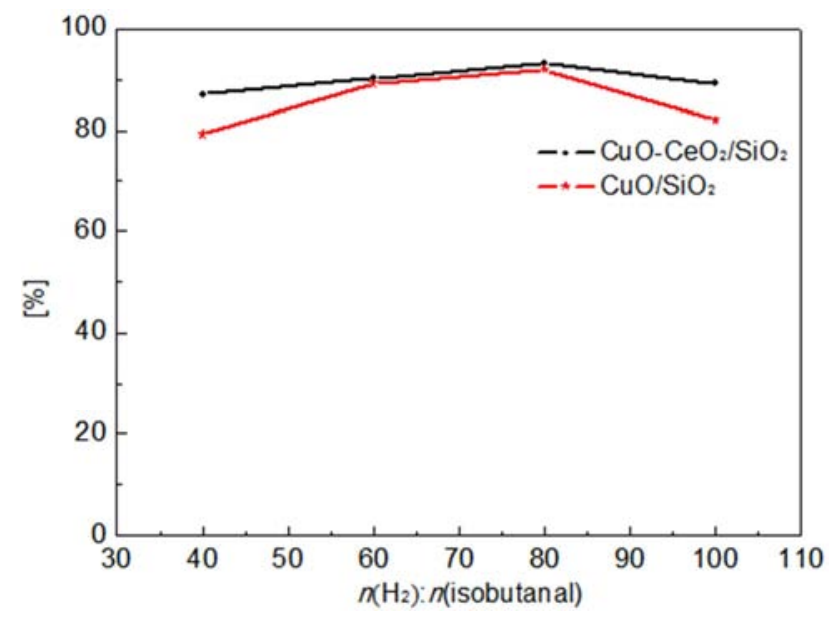

Figure 13. Influence of molar ratio of $\mathrm{H}_{2}$ to isobutanal on the yield of D-pantolactone. Reaction conditions: liquid airspeed, $0.6 \mathrm{~h}^{-1}$; temperature, $120^{\circ} \mathrm{C}$; and $\mathrm{H}_{2}$ pressure, $8 \mathrm{Mpa}$.

\section{Conclusions}

In conclusion, we have developed a chiral ionic liquid containing L-histidine unit for asymmetric aldol reaction. The aldol reaction was carried out in the presence of [EMIm] [His] (30 $\mathrm{mol} \%$ ) at room temperature. The reactions generated the corresponding products with satisfactory isolated yields and ee. It is noteworthy that [EMIm] [His] are recycled up to five times with only minor decreases in product yields, but always maintenances in ee, and its universal applicability has been demonstrated. Moreover we optimize process of $\mathrm{CuO} / \mathrm{SiO}_{2}$ and $\mathrm{CuO}-\mathrm{CeO}_{2} / \mathrm{SiO}_{2}$-catalysed hydrogenation of condensation product - (D) -3- formyl -2- hydroxy -3- ethyl butyrate to synthetize D-pantolactone in a purity of $>99 \%$, yield of $93 \%$ and high ee of $93 \%$ under a reaction temperature of $120^{\circ} \mathrm{C}, \mathrm{H}_{2}$ pressure of $8 \mathrm{MPa}, \mathrm{H}_{2}$ to isobutanal molar ratio of $80: 1$, and liquid airspeed of $0.6 \mathrm{~h}^{-1}$. Meanwhile, we find that the catalytic activity of $\mathrm{CuO}-\mathrm{CeO}_{2} / \mathrm{SiO}_{2}$ is generally higher than that of $\mathrm{CuO} / \mathrm{SiO}_{2}$ for hydrogenation.

\section{Acknowledgements}

This work was supported by grants from the National Natural Science Foundation of China (NSFC 21376128).

\section{References}

[1] Evans, D. A.; Wu, J.; Masse, C. E.; MacMillan, D. W., A General Method for the Enantioselective Synthesis of Pantolactone Derivatives. Organic letters 2002, 4, 3379-3382.

[2] O'Meara, J. A.; Gardee, N.; Jung, M.; Ben, R. N.; Durst, T., Enantioselective Synthesis of B-Dibenzylamino Alcohols Via a Dynamic Kinetic Resolution of A-Halo Acids. The Journal of Organic Chemistry 1998, 63, 3117-3119.

[3] Davies, H. M.; Ahmed, G.; Calvo, R. L.; Churchill, M. R.; Churchill, D. G., Asymmetric Synthesis of 2, 3-Dihydrofurans by Reaction of Rhodium-Stabilized Vinylcarbenoids with Vinyl Ethers. The Journal of organic chemistry 1998, 63, 2641-2645. 
[4] Hansen, M. M.; Bertsch, C. F.; Harkness, A. R.; Huff, B. E.; Hutchison, D. R.; Khau, V. V.; LeTourneau, M. E.; Martinelli, M. J.; Misner, J. W.; Peterson, B. C., An Enantioselective Synthesis of Cis Perhydroisoquinoline Ly 235959. The Journal of organic chemistry 1998, 63, 775-785.

[5] Ogawa, T.; Konno, Y.; Akashi, N.; Takasugi, H.; Sugimoto, S.; Yano, K., Process for Producing Polypeptide. Google Patents: 2009.

[6] Bonrath, W.; Netscher, T., Catalytic Processes in Vitamins Synthesis and Production. Applied Catalysis A: General 2005, $280,55-73$.

[7] Schmid, R.; Broger, E. A.; Cereghetti, M.; Crameri, Y.; Foricher, J.; Lalonde, M.; Müller, R.; Scalone, M.; Schoettel, G.; Zutter, U., New Developments in Enantioselective Hydrogenation. Pure and applied chemistry 1996, 68, 131-138.

[8] Gröger, H.; Vogl, E. M.; Shibasaki, M., New Catalytic Concepts for the Asymmetric Aldol Reaction. CHEMISTRY-WEINHEIM-EUROPEAN JOURNAL- 1998, 4, $1137-1141$

[9] Nelson, S. G., Catalyzed Enantioselective Aldol Additions of Latent Enolate Equivalents. Tetrahedron: Asymmetry 1998, 9, 357-389.

[10] Mahrwald, R., Diastereoselection in Lewis-Acid-Mediated Aldol Additions. Chemical reviews 1999, 99, 1095-1120.

[11] Machajewski, T. D.; Wong, C. H., The Catalytic Asymmetric Aldol Reaction. Angewandte Chemie International Edition 2000, 39, 1352-1375.

[12] List, B.; Lerner, R. A.; Barbas, C. F., Proline-Catalyzed Direct Asymmetric Aldol Reactions. Journal of the American Chemical Society 2000, 122, 2395-2396.

[13] Sakthivel, K.; Notz, W.; Bui, T.; Barbas, C. F., Amino Acid Catalyzed Direct Asymmetric Aldol Reactions: A Bioorganic Approach to Catalytic Asymmetric Carbon- Carbon Bond-Forming Reactions. Journal of the American Chemical Society 2001, 123, 5260-5267.

[14] List, B., Proline-Catalyzed Asymmetric Reactions. Tetrahedron 2002, 58, 5573-5590.

[15] Chen, J. -R.; Lu, H. -H.; Li, X. -Y.; Cheng, L.; Wan, J.; Xiao, W. -J., Readily Tunable and Bifunctional L-Prolinamide Derivatives: Design and Application in the Direct Enantioselective Aldol Reactions. Organic letters 2005, 7, 4543-4545.

[16] Guizzetti, S.; Benaglia, M.; Pignataro, L.; Puglisi, A., A Multifunctional Proline-Based Organic Catalyst for Enantioselective Aldol Reactions. Tetrahedron: Asymmetry 2006, 17, 2754-2760.

[17] Sathapornvajana, S.; Vilaivan, T., Prolinamides Derived from Aminophenols as Organocatalysts for Asymmetric Direct Aldol Reactions. Tetrahedron 2007, 63, 10253-10259.

[18] Bellis, E.; Kokotos, G., 4-Substituted Prolines as Organocatalysts for Aldol Reactions. Tetrahedron 2005, 61, 8669-8676.

[19] Córdova, A.; Zou, W.; Dziedzic, P.; Ibrahem, I.; Reyes, E.; Xu, Y., Direct Asymmetric Intermolecular Aldol Reactions Catalyzed by Amino Acids and Small Peptides. Chemistry-A European Journal 2006, 12, 5383-5397.

[20] Loh, T. -P.; Feng, L. -C.; Yang, H. -Y.; Yang, J. -Y., L-Proline in an Ionic Liquid as an Efficient and Reusable Catalyst for Direct Asymmetric Aldol Reactions. Tetrahedron letters 2002, 43, 8741-8743.
[21] Miao, W.; Chan, T. H., Ionic - Liquid - Supported Organocatalyst: Efficient and Recyclable Ionic - Liquid Anchored Proline for Asymmetric Aldol Reaction. Advanced Synthesis \& Catalysis 2006, 348, 1711-1718.

[22] Dupont, J.; de Souza, R. F.; Suarez, P. A., Ionic Liquid (Molten Salt) Phase Organometallic Catalysis. Chemical reviews 2002, $102,3667-3692$.

[23] Pejaković, V.; Kronberger, M.; Kalin, M., Influence of Temperature on Tribological Behaviour of Ionic Liquids as Lubricants and Lubricant Additives. Lubrication Science 2014, 26, 107-115.

[24] Liaw, H. -J.; Chen, C. -C.; Chen, Y. -C.; Chen, J. -R.; Huang, S. -K.; Liu, S. -N., Relationship between Flash Point of Ionic Liquids and Their Thermal Decomposition. Green Chemistry 2012, 14, 2001-2008.

[25] Zhou, F.; Liang, Y.; Liu, W., Ionic Liquid Lubricants: Designed Chemistry for Engineering Applications. Chemical Society Reviews 2009, 38, 2590-2599.

[26] Kim, K. -W.; Song, B.; Choi, M. -Y.; Kim, M. -J., Biocatalysis in Ionic Liquids: Markedly Enhanced Enantioselectivity of Lipase. Organic Letters 2001, 3, 1507-1509.

[27] Ulbert, O.; Fráter, T.; Bélafi-Bakó, K.; Gubicza, L., Enhanced Enantioselectivity of Candida Rugosa Lipase in Ionic Liquids as Compared to Organic Solvents. Journal of Molecular Catalysis B: Enzymatic 2004, 31, 39-45.

[28] Welton, T., Room-Temperature Ionic Liquids. Solvents for Synthesis and Catalysis. Chemical reviews 1999, 99, 2071-2084.

[29] He, L.; Qin, S.; Chang, T.; Sun, Y.; Gao, X., Biodiesel Synthesis from the Esterification of Free Fatty Acids and Alcohol Catalyzed by Long-Chain Brønsted Acid Ionic Liquid. Catalysis Science \& Technology 2013, 3, 1102-1107.

[30] Panday, S. K., Advances in the Chemistry of Proline and Its Derivatives: An Excellent Amino Acid with Versatile Applications in Asymmetric Synthesis. Tetrahedron: Asymmetry 2011, 22, 1817-1847.

[31] Zhou, L.; Wang, L., Chiral Ionic Liquid Containing L-Proline Unit as a Highly Efficient and Recyclable Asymmetric Organocatalyst for Aldol Reaction. Chemistry letters 2007, 36, 628-629.

[32] Dasari, M. A.; Kiatsimkul, P.-P.; Sutterlin, W. R.; Suppes, G. J., Low-Pressure Hydrogenolysis of Glycerol to Propylene Glycol. Applied Catalysis A: General 2005, 281, 225-231.

[33] Huang, L.; Zhu, Y.; Zheng, H.; Ding, G.; Li, Y., Direct Conversion of Glycerol into 1, 3-Propanediol over $\mathrm{Cu}-\mathrm{H} 4 \mathrm{siw} 12 \mathrm{o} 40 / \mathrm{SiO}_{2}$ in Vapor Phase. Catalysis letters 2009, $131,312-320$

[34] Vasiliadou, E.; Lemonidou, A., Investigating the Performance and Deactivation Behaviour of Silica-Supported Copper Catalysts in Glycerol Hydrogenolysis. Applied Catalysis A: General 2011, 396, 177-185.

[35] Zhao, M.; Wang, J., Study on Preparation of Ionic Liquid Mediates. Chemical Industry Times 2004, 18, 22-23.

[36] Wu, X.; Lv, Z.; Zhang, W., New Technology for Green Synthesis of $\alpha$-Hydroxy- $\beta, \beta$-dimethyl- $\gamma$-butyrolactone. Journal of Qingdao University of Science and Technology (Natural Science Edition) 2011, 32, 446-450. 